Open Access

Research Article
Res. Agric. Livest. Fish. Vol. 2, No. 2, August 2015: 363-368

\title{
SOCIO-ECONOMIC STATUS OF KUCHIA CATCHERS AT PURBADHALA UPAZILA UNDER NETROKONA DISTRICT
}

\section{Rabeya Rahmatullah*, Plabon Sarker and Shah Mohammad Rahmatullah}

Department of Aquaculture, Faculty of Fisheries, Bangladesh Agricultural University, Mymensingh-2202, Bangladesh

*Corresponding author: Rabeya Rahmatullah, E-mail: tori.baufiish@yahoo.com

\section{ARTICLE INFO \\ ABSTRACT}

Received

22.07.2015

Accepted

27.08.2015

Online

04.09.2015

Key words

Socio-economic Kuchia

Catcher
A study was carried out to observe the present socio-economic status of kuchia catchers at Purbadhala upazila under Netrokona district. Data were collected over a period of five months from May to September 2014 by interviewing kuchia catchers. The study showed that the highest percentage $(42.5 \%)$ of kuchia catchers belonged to the age group of 21 25 years and $75 \%$ of them were ethnic people. Family consisting of $4-5$ members was the highest $(47.5 \%) .48 \%$ of the kuchia catchers of the study area were educated up to primary school. Among the selected kuchia catchers, $82.5 \%$ depended on village doctors during their health problems and $62 \%$ of them were deprived of sanitation facilities. Kuchia catching was the main source of income of the catchers that were interviewed. The highest percentages $(70 \%)$ of kuchia catchers had monthly income between 10200 11000 Taka.

To cite this article: R Rahmatullah, P Sarker and SM Rahmatullah, 2015. Socio-economic status of kuchia catchers at Purbadhala upazila under Netrokona district. Res. Agric. Livest. Fish. 2 (2): 363-368. 


\section{INTRODUCTION}

Freshwater mud eel or swamp eel, M. cuchia, also known as Kuchia or Kucha belonging to the family Synbranchidae commonly occurs in freshwater of Bangladesh, Pakistan and throughout India (Jhingran and Talwar, 1991). It is available in plenty throughout Bangladesh in mud holes, shallow beels and boro-paddy fields particularly in Sylhet, Mymensingh and Tangail districts (Rahman, 1989). It has specialized pharyngeal pouches for bimodial gas exchange (Huges and Munshi, 1973; Munshi, 1985). M. cuchia has remarkable ability to distend respiratory air sac for gas exchange (Mishra et al., 1977).

Kuchia has great demand in the international market which is contributing to earn foreign currencies. Bangladesh exported 7157 metric ton kuchia in 2012-2013 which is equivalent to 14.49 million US \$ (Rouf, 2014). But M. cuchia is a vulnerable species in Bangladesh (IUCN, 2000). The natural stock of kuchia is decreasing day by day due to over exploitation. Other causes for the reduction of kuchia population is habitat destruction through blockage of water flow, shallow water depth, encroachment by agriculture and aquaculture, indiscriminate use of chemicals like fertilizers and pesticides, development of flood control structures and fishing in breeding season (DoF, 2014).

Fishermen are one of the most vulnerable communities in Bangladesh. Their per capita annual income is BDT 2,442 i.e. about $70 \%$ lower than the per capita income of the country as a whole (Alam and Bashar, 1995). The scenario is similar for the kuchia catchers. Long ago, only ethnic people were directly related to kuchia catching for income generation. Now-a-days, the non-ethnic people are also engaging in this occupation due to the high market price of kuchia. However, the kuchia catchers are very poor and are deprived of many amenities of life. A socio-economic study is will help to identify the constraints and threats of their livelihood and to formulate alleviating measures for improvements of their live and living as a whole. A scientific approach will also help to identify the class of people involved in the profession and take measures to prevent the overexploitation of kuchia. The focus of this article is to describe the socio-economic status of kuchia catchers at Purbadhala upazila under Netrokona district.

\section{MATERIALS AND METHODS}

Purbadhala upazilla under Netrokona district was selected as the study area mainly because of the inhabitance of ethnic people (Garo) in the area. It is known that ethnic people were primarily engaged in kuchua catching though non-ethnic people are now also getting involved.

Questionnaires and focus group discussion (FGD) were the main tools of data collection. About 40 kuchia catchers were selected by Simple Random Method to see the socio-economic status of kuchia catchers in the selected area. Kuchia catchers are those persons who catch kuchia from natural sources and sell them for earning money to lead their lives. Data were collected from May to September 2014. The collected data were justified by the Upazilla Fisheries Officer (UFO) of that area.

The data were then accumulated, grouped, and interpreted in accordance with the objectives of this study. The collected data were numeric and narrative. These data were edited and summarized in this study. All the data were statistically analyzed by Microsoft Excel and SPPS (Statistical Package for Social Science) software.

\section{RESULTS AND DISCUSSION}

Socio-economic status of kuchia catchers which was one of the objective of the study was completed by collecting data on age structures, religious status, family size, educational level of kuchia catchers, housing condition, drinking water facilities, health facilities, sanitation facilities, electricity facilities, monthly income etc. from the kuchia catchers. These are presented in Table 1. 
Table 1. Socio-economic characteristics of kuchia catchers in Purbadhala upazila, Netrokona

\begin{tabular}{|c|c|}
\hline Characteristics & Percentage \\
\hline \multicolumn{2}{|l|}{ Age structures } \\
\hline $16-10$ & 22.5 \\
\hline $21-25$ & 42.5 \\
\hline $26-30$ & 15 \\
\hline $31-35$ & 10 \\
\hline $36-40$ & 7.5 \\
\hline Above 40 & 2.5 \\
\hline \multicolumn{2}{|l|}{ Religious status } \\
\hline Christian & 75 \\
\hline Hindu & 15 \\
\hline Muslim & 10 \\
\hline \multicolumn{2}{|l|}{ Family size } \\
\hline $2-3$ & 22.5 \\
\hline $4-5$ & 47.5 \\
\hline $6-7$ & 17.5 \\
\hline Above 7 & 12.5 \\
\hline \multicolumn{2}{|l|}{ Educational level } \\
\hline Illiterate & 20 \\
\hline Only able to sign & 27 \\
\hline Up o primary school & 48 \\
\hline Up to high school & 5 \\
\hline \multicolumn{2}{|l|}{ Housing condition } \\
\hline Kacha house & 73 \\
\hline Tin house & 27 \\
\hline \multicolumn{2}{|l|}{ Drinking water facilities } \\
\hline Own tube well & 80 \\
\hline Others tube well & 20 \\
\hline \multicolumn{2}{|l|}{ Health facilities } \\
\hline Village doctor & 82.5 \\
\hline Upazila health complex & 17.5 \\
\hline \multicolumn{2}{|l|}{ Sanitation facilities } \\
\hline Kacha toilet & 62 \\
\hline Semi-pucca toilet & 38 \\
\hline \multicolumn{2}{|l|}{ Electricity facilities } \\
\hline Yes & 12.5 \\
\hline No & 87.5 \\
\hline \multicolumn{2}{|l|}{ Monthly income (BDT) } \\
\hline $8000-9000$ & 10 \\
\hline $9001-10000$ & 12.5 \\
\hline $10001-11000$ & 70 \\
\hline $11001-12000$ & 7.5 \\
\hline
\end{tabular}

\section{Age structures}

Different age groups of kuchia catchers were involved in catching of kuchia at Purbadhala upazilla of Netrokona district. The age range of $21-25$ years was mostly dominant (42.5\%) in catching of kuchia whereas $22.5 \%$ were in the age range of $16-20$ years, $15 \%$ were in the age range of $26-30$ years, $10 \%$ were in the age range of 31-35 years, $7.5 \%$ were in the age range of $36-40$ years and $2.5 \%$ were in the age range of above 40 years. Rahman (2013) found that $57.9 \%$ of crab fatteners belonged to the age range of $38-46$ years in Khulna 
region and Khatun (2012) found that 50\% kuchia catchers were in the age group of 31-40 years at Paikgacha upazila of Khulna that is not similar to the present study. This dissimilarity may be attributed to personal choice, physical capabilities and entrance of the kuchia catchers in this profession at their early stage of life owing to poor economic conditions of their parents.

\section{Religious status}

Long ago, catching of kuchia was not as popular as present time and was caught only by the ethnic people such as Garo. Now-a-days, many non-ethnic people are also involved in kuchia catching because of the economic value. The graphical representation shows that $75 \%$ of the kuchia catchers were ethnic and $25 \%$ of them were non-ethnic. As the majority of kuchia catchers were ethnic people, they were the followers of Christian religion. Now-a-days, people of other religion such as Hindus and Muslims are getting involved kuchia catching. The highest percentage of kuchia catchers were Christians (75\%) whereas 15\% were Hindus and $10 \%$ were Muslims. Islam (2006) found in his study area in Lalmonirhat sadar upazila that $80 \%$ fish farmers were Muslims and $20 \%$ were Hindus and Khatun (2012) found that $89.29 \%$ of kuchia catchers were Hindus and $10.71 \%$ were Muslims at Paikgacha upazila of Khulna which is not similar to present study. This is because the percentage of ethnic people was high in the study area because they involved in kuchia catching as their family tradition. Now the number of non-ethnic people is increasing due to the high market price and high demand of kuchia in national and international market.

\section{Family size}

There were four types of family size: 2 to 3 members, 4 to 5 members, 6 to 7 members and above 7 members added in the questionnaire. Result showed that $47.5 \%$ kuchia catchers had 4 to 5 members in their family which was the highest percentage and $12.5 \%$ catchers belonged to above 7 members in their family which was the lowest percentage. At present, family size is decreasing among the kuchia catchers. Khatun (2012) found that $42.86 \%$ of kuchia catchers had 6-7 members in their family at Paikgacha upazila of Khulna and Farid (2013) found that $48 \%$ crab fatteners had 4-5 family members in Shyamnagar upazila of Satkhira district which is not similar to Khatun's study but similar to Farid's study.

\section{Educational level of the kuchia catchers}

Kuchia catchers lived below the poverty line. So their educational level was not very high. The education level of kuchia catchers in the study area reveals that $20 \%$ were illiterate, $27 \%$ were only able to sign their name, $48 \%$ were educated up to primary school and $5 \%$ were educated up to high school. In this study, some catchers studied up to class six to class seven which is presented in the high school category. The education level of the study area was not good due to unconsciousness about education, lack of educational institutions and disability to bear the educational cost of school going children of kuchia catchers due to the poverty of kuchia catchers. But, at present the number of literacy people is increasing day by day. Robbani (2007) reported that $20 \%$ of fishermen were illiterate, $71.67 \%$ of fishermen were up to primary level of education and $8.33 \%$ were only secondary level of education which is similar pattern of present study.

\section{Housing condition}

The housing condition of the kuchia catchers was not so good, most of them had kacha house which means the roof was made of straw and fence was made of bamboo split and with mud flooring while some had tin house which means the roof was shaded by tin but the wall was made of bamboo split and with mud flooring. The percentages found in that area were $73 \%$ kacha house and $27 \%$ tin house. The result matches the findings of Islam (2009) who observed that about $75 \%$ of the fishermen's houses were katcha.

\section{Drinking water facilities}

The source of drinking water was tube-well in the study area. It was observed that almost $80 \%$ kuchia catchers had own tube-wells and rest $20 \%$ had no own tube-wells who were dependent on those provided by the local government or neighbors tube-well for drinking purpose. Similar results were also noted by Chowdhury (2012); Hossain (2012). 


\section{Health facilities}

At Purbadhala upazila, when the kuchia catchers faced health problem, they would either go to the village doctors (owner or salesmen of dispensary or Quack) or Upazila Health Complex to solve their problems. It was seen that $82.5 \%$ kuchia catchers were dependent on village doctors and $17.5 \%$ of them went to Upazila Health Complex during their health problems. There were also similar patterns of result noted by Zafar and Ahsan (2006) and Khatun (2012).

\section{Sanitation facilities}

Sanitary conditions of the kuchia catchers were poor.Among the interviewees, the catchers who possessed kacha toilet were $62 \%$ due to poverty and the remaining $38 \%$ possessed semi-pucca toilet. Khatun (2012) reported that $57.14 \%$ kuchia catchers had sanitary toilet and $42.46 \%$ had katcha toilet. The finding is not similar to present study because they were not conscious about hygiene, environment and curse of poverty.

\section{Electricity facilities}

The electricity facility of study area was not good. In the selected area, only $12.5 \%$ catchers used electricity by drawing line from nearby village which was illegal and $87.5 \%$ catchers lived without electricity facility. Zafar and Ahsan (2006) reported that only $18 \%$ of the crab collectors in Khulna and Satkhira district had electricity facility and Khatun (2012) reported that $21.43 \%$ of the kuchia catchers at Paikgacha in Khulna district had electricity facility that is more or less similar to present study.

\section{Monthly income}

Catching of kuchia by hand or fish trap (locally called Bair) or rod and hook (locally called Borshi) from mud holes, shallow beels and boro-paddy fields and selling them to the paikers (bepari) was the main source of income of kuchia catchers of the study area. Few catchers were also involved in other income generating activities. It was observed that $57.5 \%$ kuchia catchers depended solely on kuchia catching whereas $22.5 \%$ kuchia catchers involved in agriculture, 10\% kuchia catchers involved in fishing and $12.5 \%$ kuchia catchers involved in labor respectively as an additional source of income. The other sources of income had very little effect on the socio-economic status of the kuchia catchers involved.

The monthly income of $70 \%$ kuchia catchers were in the range of $10001-11000$ Taka whereas $10 \%$ kuchia catchers were in the range of 8000-9000 Taka, 12.5\% kuchia catchers were in the range of 9001-10000 Taka and $7.5 \%$ kuchia catchers were in the range of 11001-12000 Taka respectively. This income was generated only by selling the kuchia they caught. Molla et al. (2009) reported that in Khulna and Satkhira district, 45\% crab fatteners earned monthly a range of 7500-12500 Tk. which is similar to the present study.

\section{CONCLUSION}

The findings establish that mostly poor people who are lacking the amenities of life are primarily engaged in kuchia catching in the study area. Their poverty is the reason of their lower education level which in turn affects the family size because they think that a higher number of family members will result in higher income levels. The government and NGOs should come forward to help improve their socio-economic conditions. The government should undertake motivational programs to encourage the kuchia catchers to involve in other sources of income besides kuchia catching.

\section{COMPETING INTEREST}

The authors declare that they have no competing interests. 


\section{REFERENCES}

1. Alam MF and Bashar MA, 1995. Structure of cost and profitability of small scale riverine fishing in Bangladesh. Journal of Research and Progress, 9: 235-241.

2. Chowdhury AKJ, 2012. Investigation on livelihood status of hilsa fishing communities in Lakshmipur district, MS Thesis, Department of Fisheries Management, Bangladesh Agricultural University, Mymensingh.

3. DoF, 2014. Department of Fisheries. National Fish Week 2014 Compendium (In Bengali), Ministry of Fisheries and Livestock, Bangladesh. pp. 38.

4. Farid BMSAB, 2013. The Potential of Crab Harvesting and Fattening as Sources of Sustainable Climate Resilience for the Coastal Poor People, MS Thesis, Department of Fisheries Management, Bangladesh Agricultural University, Mymensingh.

5. Hossain FI, 2012. Study on the fisheries and socio-economic condition of fishermen of the Punarvhaba river in sadar upazila, Dinajpur district, MS Thesis, Department of Fisheries Management, Bangladesh Agricultural University, Mymensingh.

6. Hughes GM and JSD Munshi, 1973. Nature of airbreathing organs of the Indian fishes Channa, Amphipnous, Clarias and Saccobranchus as shown by electron microscopy. Journal of Zoology, London, 170: 245-270.

7. Islam MA, 2009. Socio-economic conditions of the fishing community living in the Kali river banks in Bhairab upazila of Kishorgonj district, MS Thesis, Department of Fisheries Management, Bangladesh Agricultural University, Mymensingh.

8. Islam MR, 2006. Study of fish farming and the livelihood of the fish farmers of sadar upazila in Lalmonirhat District, MS Thesis, Department of Aquaculture, Bangladesh Agricultural University, Mymensingh.

9. IUCN, 2000. Red Book of Threatened Fishes of Bangladesh. The world Conservation Union, Dhaka, Bangladesh. pp.116.

10. Jhingran AG and PK Tawlar, 1991. Inland fisheries of India and adjacent countries. Oxford and IBH publishing co. Pvt. Calcutta 1514.

11. Khatun MS, 2012. Marketing activities of Kuchia (Monopterus cuchia) and socio-economic condition of coastal people involed in Kuchia catching at Paikgacha upazila of Khulna, MS Theis, Department of Aquaculture, Bangladesh Agricultural University, Mymensingh.

12. Mishra N, PK Pandey and JSD Munshi, 1977. Haematological parameters of an air-breathing mud eel, Amphipnous cuchia (Ham.) (Amphipnoidae; Pisces). Journal of Fish Biology, 10: 567-573.

13. Molla MAG, MR Islam, S Islam and MA Salam, 2009. Socio-economic status of crab collectors and fatteners in the southwest region of Bangladesh. Journal of Bangladesh Agricultural University, 7: 411-419.

14. Munshi JSD, 1985. The structure, function and evolution of the accessory organs of air-breathing fishes of India. In: vertebrate morphology (eds. Duncker and Fleischer), New York: Gustav Fischer. pp. 353-366.

15. Rahman AKA, 1989. Freshwater fishes of Bangladesh. Zoological Society of Bangladesh, University of Dhaka. pp. 364.

16. Rahman MA, 2013. Improvement of socio-economic status of poor crab fattener, MS Theis, Department of Aquaculture, Bangladesh Agricultural University, Mymensingh.

17. Robbani MG, 2007. Fisheries and socio-economic condition of fishermen of Karatoa River, MS Thesis, Department of Fisheries Management, Bangladesh Agricultural University, Mymensingh.

18. Rouf JM, 2014. Ashajaganiya kuche, Kalerkantho. pp. 18 (WWW. Kalerkantho.com, 30 November).

19. Zafar M and MN Ahsan, 2006. Marketing and value chain analysis of mud crab (Scylla $s p$.) in the coastal communities of Bangladesh. Bangladesh Fisheries Research Forum. pp. 25-53. 